\title{
LONGITUDINAL STUDY OF CALCIUM AND BONE METABOLISM IN PARAPLEGIC PATIENTS*
}

\author{
By P. Bergmann, ${ }^{1}$ A. Heilporn, ${ }^{2}$ A. Schoutens, ${ }^{3}$ J. Paternot ${ }^{3}$ and \\ A. TRICOT ${ }^{2}$ \\ ${ }^{1}$ Fonds National de la Recherche Scientifique Belge; ${ }^{2}$ Centre de Traumatologie et de \\ Readaptation (U.L.B.); ${ }^{3}$ Service de Médecine (Département des Radioisotopes), Hôpital \\ Universitaire Brugmann, Brussels, Belgium
}

Abstract. A longitudinal study of bone and calcium metabolism in 28 patients with spinal chord lesion shows an enhancement of bone calcium accretion, generalized to the whole skeleton. The bone calcium turnover rate is more increased in the non-paralysed area during the first 2 months.

Key words: Bone metabolism; calcium metabolism.

\section{Introduction}

A SPINAL cord injury is followed by a rapid mineral loss from the skeleton of the paralysed region. The X-rays point initially to the epiphyseal and metaphyseal areas where radiotranslucent horizontal bands develop. There is also some blurring of the limit between cortical bone and medullary canal. However, the thickness of the bone shaft remains unchanged (Chantraine et al., 1975).

Massive mobilisation of calcium and phosphorus certainly plays a prominent role in the development of the ectopic paraosteoarthropathic calcifications (POA) which occur in I6 per cent of such patients (Tricot, I972). Local factors favouring the occurrence of this complication are probably traumas, circulatory disturbances, abnormal biochemical conditions (amino acid composition was found abnormal in infralesional bone (Nusgens et al., I975)), high phosphorus and ionised calcium in serum (Heath et al., I973). The ectopic bone is trabecular, poorly mineralised; its very fast turnover is well illustrated by the histological data of enhanced osteoclastic resorption surfaces and osteoid seams, as well as by the increased radiostrontium uptake (Muheim et al., 1973). Mineral crystals are small and amorphous mineral is abundant (Baud et al., I972), pointing to the immaturity of this newly formed bone.

Some authors (Decoulx et al., I952; Galibert et al., I96I) suggest that abnormal calcium metabolism in the paralysed regions could be related to the autonomous nervous system lesion and its subsequent circulatory disturbances.

In this study, we checked the evolution of regional bone turnover and of circulation in the legs of patients with spinal injuries. As our first data indicated a modification of bone metabolism in the whole body, we extended the scope of this work to the search of pathological endocrine factors.

\section{Patients (Table I)}

\section{Material and Methods}

Twenty-two men and six women, I6.5 to 56 years old, are serially studied after their admission to the rehabilitation centre which for 23 of them takes place

* Supported in part by contract no. $3,4506,75$ with the F.R.S.M. 


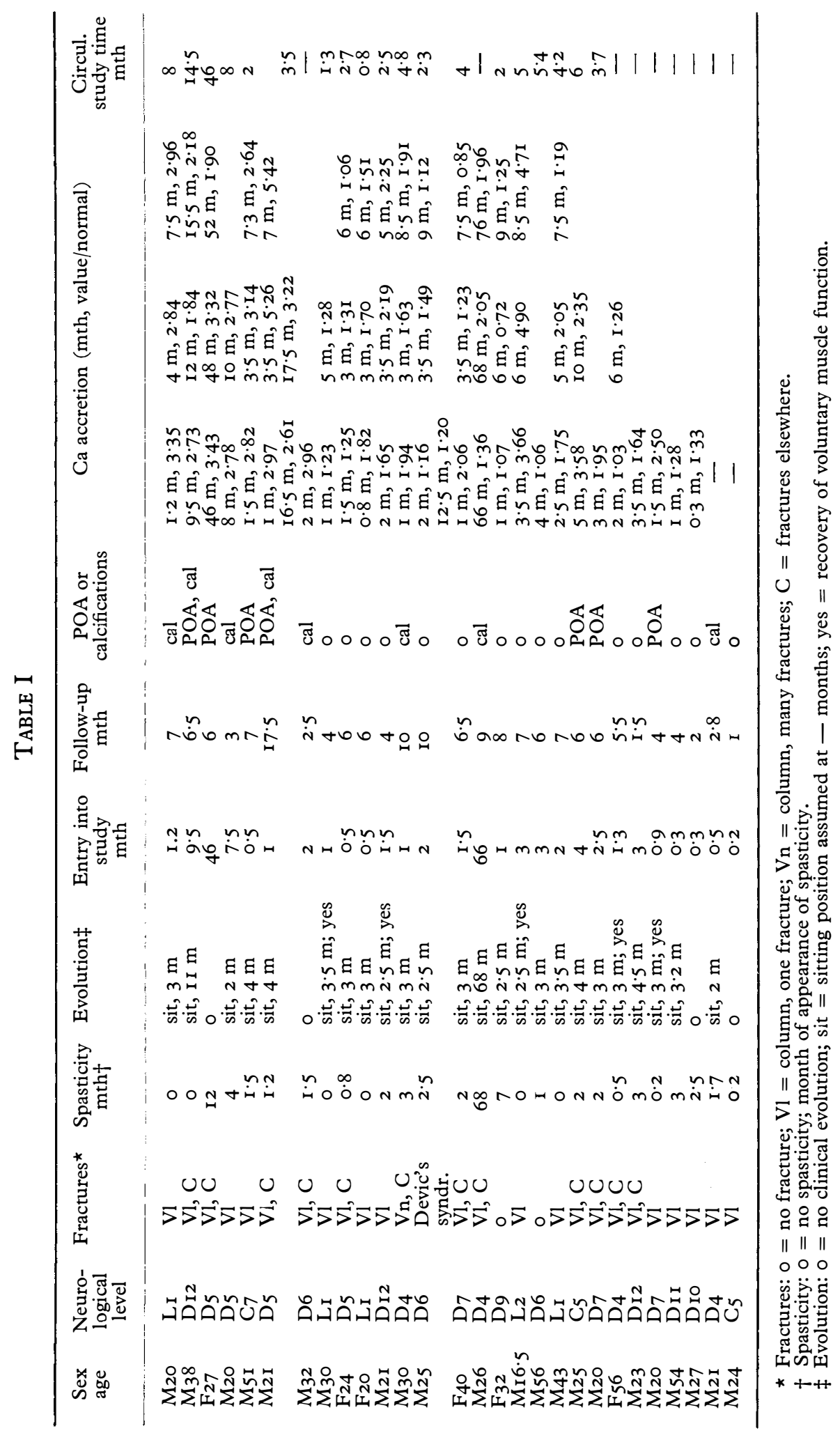


during the 3 months following the spinal cord injury. Trauma is the cause of the lesion in 27; one patient has a Devic's syndrome. No fracture is evident in three. Neurological level varies from $\mathrm{C}_{5}$ to $\mathrm{L}_{\mathrm{I}}$. Five patients recover a voluntary motility. Seven develop POA calcifications; moreover, very small calcifications in the periarticular regions are encountered in 8.

\section{Methods}

Measured parameters, methods used and frequency of measurements are listed in Table II. Two techniques have to be described, the measurement of regional bone calcium accretion and the study of circulation in the legs.

Accretion is the amount of calcium which is trapped daily by the skeleton, either by new bone apposition, secondary mineralisation or slow exchange. It measures bone remodelling. Intravenous injection of $\mathrm{Ca} 47$ is followed during 6 to Io days by measurements of whole body and regional retentions of the isotope and by serum specific activity determinations. After 48 to 72 hours, the serum activity curve can be fitted by a single exponential of slope $\lambda$ supposed to represent the evolution of the extraosseous pool activity. For every time $t$ regional retention is the sum of an extraosseous component which is the activity measured at 4 hours

\section{TABLE II}

\begin{tabular}{|c|c|c|c|}
\hline Parameters & Frequency & Methods & Normal values \\
\hline \multicolumn{4}{|l|}{ Blood } \\
\hline $\mathrm{Ca}$ & Monthly & & $9.4-10.8 \mathrm{mg} \%$ \\
\hline$P$ & Monthly & & $2.5-4.5 \mathrm{mg} \%$ \\
\hline Alkaline phosphates & Monthly & & $<$ I 2 KA units \\
\hline \multicolumn{4}{|l|}{ Urine } \\
\hline$\stackrel{\mathrm{Ca}}{\mathrm{P}}$ & Twice monthly & & $<0.2 \mathrm{mg} / \mathrm{mg}$ creatinine \\
\hline Hydroxyproline & Twice monthly & & $\begin{array}{l}0.75 \mathrm{mg} / \mathrm{mg} \text { creatinıne } \\
<40 \gamma / \mathrm{mg} \text { creatinine }\end{array}$ \\
\hline \multicolumn{4}{|l|}{ Endocrinology } \\
\hline PTH & 2 measures & RIA $\left(\mathrm{NH}_{2}\right.$ term $)$ & \\
\hline $\begin{array}{l}\text { Cortisol } \\
\text { ACTH }\end{array}$ & $\begin{array}{l}\text { I measure } \\
\text { I measure }\end{array}$ & & \\
\hline $\begin{array}{l}\text { ACTH } \\
\text { STH }\end{array}$ & I measure & RIA & \\
\hline STH & I measure & RIA & \\
\hline $\begin{array}{l}\mathrm{T}_{4} / \mathrm{T}_{3} / \mathrm{T}_{4} \mathrm{FI} \\
\mathrm{TSH}\end{array}$ & $\begin{array}{l}\text { I measure } \\
\text { I measure }\end{array}$ & $\begin{array}{l}\text { RIA; radiocompetition } \\
\text { RIA }\end{array}$ & \\
\hline $\begin{array}{l}\text { I7 } \mathrm{OH} / \mathrm{I} 7 \text { ceto } \\
\text { stéroides }\end{array}$ & I measure & & $\begin{array}{l}\text { I7 OH: } M \text { 5-I6; F 3-10 mg/24 h } \\
\text { I7 ceto: } M \text { I } 2-24 ; F 8-20 \mathrm{mg} / 24 \mathrm{~h}\end{array}$ \\
\hline 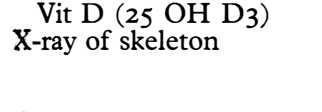 & $\begin{array}{l}\text { O, } 3 \text { and } 6 \text { months } \\
\text { after entry into } \\
\text { study }\end{array}$ & Radiocompetion & \\
\hline Calcium accretion & $\begin{array}{l}0,3 \text { and } 6 \\
\text { months }\end{array}$ & See text & $35-570 \mathrm{mg} / 24 \mathrm{~h}$ \\
\hline Calcium absorption & I measure & $\begin{array}{l}2 \text { isotopes of } \mathrm{Ca} \text {, per } \\
\text { os and IV }\end{array}$ & $20-40 \%$ ingested dose \\
\hline Leg circulation study & I measure & $\begin{array}{l}\text { intra fem. art. inj. } \\
\text { of MAI. See text }\end{array}$ & $\begin{array}{l}\text { A.V. shunt: } 4 \cdot 3 \pm 3 \cdot 9 \% \\
R_{1} / R_{2}: 7 \cdot 4 \pm 6 \cdot 4 \%\end{array}$ \\
\hline Mineralometry & Weekly & $\begin{array}{l}\text { gamma absorptio- } \\
\text { metry (Cameron) }\end{array}$ & $\begin{array}{l}20-55 \text { years: } \\
\text { M: I. IO-I. } 35 \mathrm{~g} / \mathrm{cm} ; \mathrm{F}: 0 \cdot 79-\mathrm{I} \cdot 0 \mathrm{I} \mathrm{g} / \mathrm{cm}\end{array}$ \\
\hline Bone biopsy & I measure & $\begin{array}{l}\text { decalcified and non- } \\
\text { decalcified bone hist. } \\
\text { bone density gradient } \\
\text { analysis (Lapiere) } \\
\text { bone collagen } \\
\text { analysis (Lapiere) }\end{array}$ & \\
\hline
\end{tabular}

I $5 / 2-D$ 
(osseous activity is then negligible) times $\mathrm{e}^{-\lambda(t-4 \mathrm{~h})}$, and of an osseous component or accreted activity. Deposition of calcium into bone is supposed to proceed from the serum. Henceforth, the calculation of accretion is (Bergmann et al., 1975):

$$
A_{i}=\frac{R_{i}(T)-R_{i}(4 \mathrm{~h}) \times \mathrm{e}^{-\lambda(T-4 h)}}{\int_{0}^{T} a_{s}(t) d t}
$$

where $A_{i}=$ accretion of calcium in region $i$ in $\mathrm{mg} / 24 \mathrm{~h}$

$R_{i}(t)=$ retention of activity at time $t$ in region $i$

$\lambda=$ slope of the exponential which adjusts the serum specific activity curve

$a_{s}(t)=$ serum specific activity at time $t$.

This formula gives results identical to those obtained by the Bauer-CarlssonLindquist formula (Bauer et al., I956; Marshall, I969).

Circulation in the leg is studied after intrafemoral artery injection of albumin microspheres of 30 microns (Fig. 7). They are temporarily blocked at the arteriolar level. The presence in the leg of arteriovenous communications greater than 30 microns leads to the embolisation of the beads into the lungs (Rhodes et al., I972). The activity profile along the long axis of the body enables us to determine the arteriovenous shunt of the leg (activity in the lungs divided by the total activity) and a distal vascularisation index obtained by dividing activity in the foot by that in the leg $\left(R_{1} / R_{2}\right)$.

\section{Biology}

\section{Results}

Calcaemia is usually normal, but dispersion of the results is slightly greater than in a normal population: out of $I 73$ determinations, I 9 fall outside the mean \pm 2 S.D. (I I higher, 8 lower). During the first 3 months following spinal cord injury, serum phosphorus is increased. The mean of 47 measurements in 23 patients is $4.50 \pm 0.42 \mathrm{mg}$ per cent. Sixteen patients have at least one high value. After 5 months the mean of 67 phosphorus measurements in 17 patients is significantly lower $(4 \cdot 10 \pm 0.55 \mathrm{mg}$ per cent; $0.00 \mathrm{I}<\mathrm{P}<0.005)$ (Fig. I).

Out of I 79 serum alkaline phosphatases determinations, I 23 are high. Every patient has at least one increased alkaline phosphatases value though only seven of them have POA. This enzyme may increase late in the course of the disease, independently of hydroxyprolinuria or calciuria, and without concomitant clinical incidents.

There is a peak in calciuria and hydroxyprolinuria 3 months after spinal injury. Mean peak values are respectively $350 \mathrm{mg} \mathrm{Ca} /$ day and $107 \gamma$ hydroxyproline/mg creatinine. Phosphaturia is already maximal at the beginning of the follow-up; it seems to decrease slowly with time.

There is a moderate correlation between hydroxyprolinuria and serum alkaline phosphatases as well as between hydroxyprolinuria and calciuria.

\section{Endocrine Function}

PTH is measured 19 times in nine patients. Two values are increased, always preceded or followed by a normal figure. Thyroid hormones are normal in eight patients. Two growth hormone determinations are normal. Serum 25-OH 

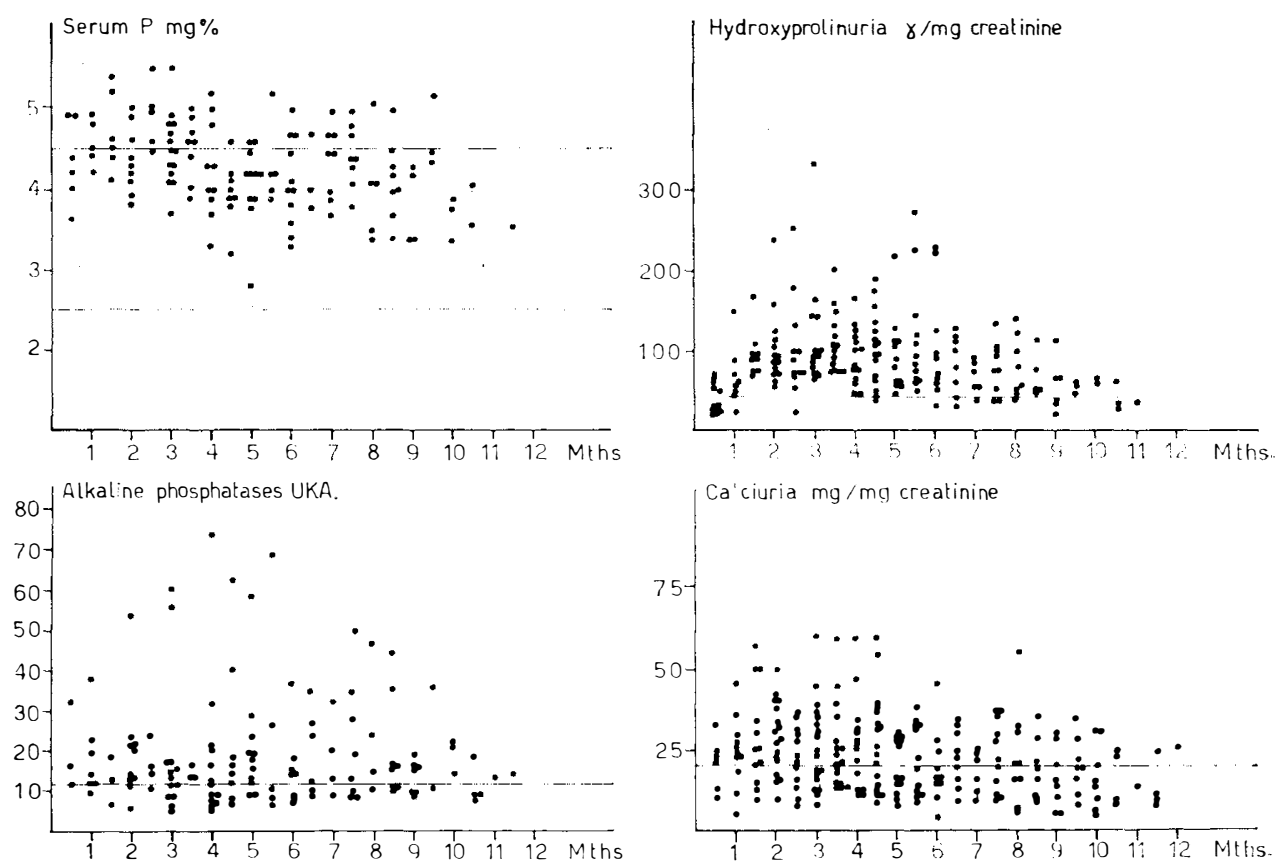

FIG. I

Serum phosphorus and alkaline phosphatases, urinary calcium and hydroxyproline in 26 paraplegic patients as a function of time following the injury. The lines embrace the normal values for these parameters.

cholecalciferol is normal or increased supposedly by Vitamin D intake. Corticosteroid metabolism is abnormal: out of I7 serum ACTH and urine steroids determinations, only eight are normal. Seven patients have a decreased urinary steroids output, five with increased ACTH, two with normal ACTH. One patient has an increased urinary steroids output associated with an increased ACTH value. The last patient has an increased ACTH with normal urinary steroid output (Fig. 2).

\section{Histology}

Four needle biopsies are taken from the iliac crest. Their histological pattern is normal. Out of three tibial plate biopsies, two are histologically normal. In a third patient, bone is composed of thin osseous trabeculae with several resorption lacunae; some of them are partially filled with fibrous tissue. This aspect is similar to that of hyperparathyroid osteitis. Three POA are biopsied: they consist of spongy bone. Abundant osteoid substance is present along with numerous resorption lacunae containing small osteoclasts.

\section{Intestinal Calcium Absorption}

Seven measures were done in six patients. Four values are normal, two are increased, one is low. Calcium absorption does not seem to be related to the duration of the disease. 


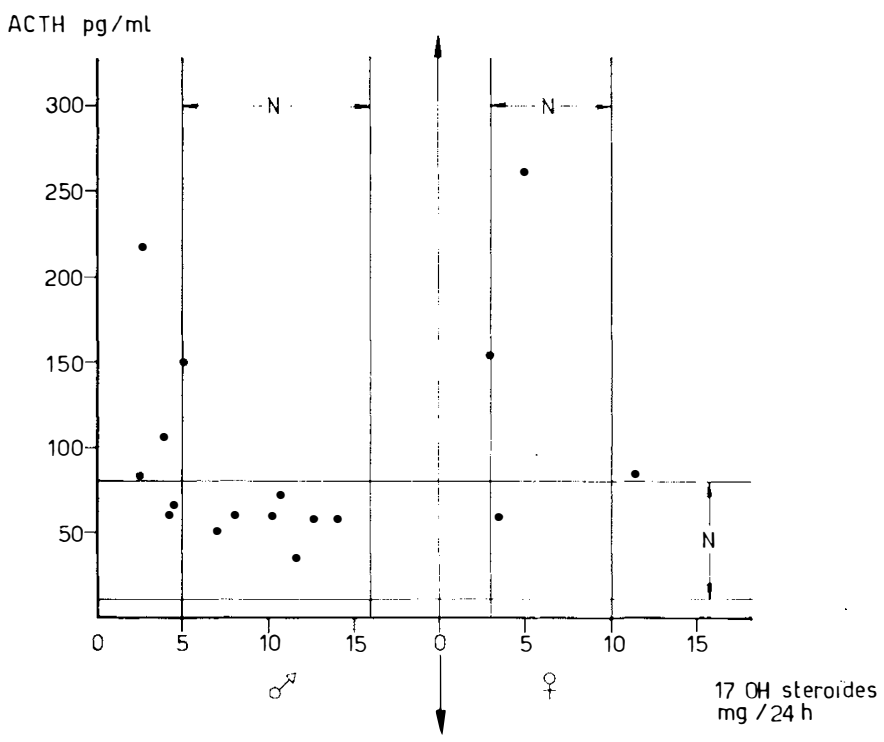

FIG. 2

The adrenocortical function in paraplegic patients.

\section{Regional Bone Calcium Accretion}

Out of 64 measurements in 26 patients, 64 per cent are increased; 69 per cent of patients present at least one high value. Mean accretion is twice the normal, with a slightly lower value during the 2 first months compared with later.

If only areas without fractures or POA are considered for the accretion measurements, high values are still found with a peak between 3 and Io months (Fig. 3).

A fairly good correlation exists between accretion and hydroxyprolinuria (Fig. 4) though a dissociation between the evolution of these parameters is often encountered in individual cases. Increase is independent of the neurological level.

Out of five patients who recover a voluntary motricity, two have a normal accretion value, three an increased or very increased one. Three patients present without fracture: accretion is normal for two, increased for one. The survey of the clinical data of five patients whose accretion value is normal during the 2 first months doesn't yield any indication pointing to a common pattern.

Results of regional measurements are unexpected as accretion is found to be higher in the skeleton of the non-paralysed regions during the first 2 months. Without taking into account areas with fractures or POA, the following is observed (Fig. 5) concerning the relationship between infralesional and supralesional skeleton: bone turnover is significantly increased in the supralesional area during the first 12 months accretion; increase in the infralesional skeleton remains increased after 12 months. Values between 2 and 12 months are higher than those obtained during the 2 first months following the spinal cord injury; the supralesional to the infralesional accretion ratio is $I \cdot 4$ during the first 2 months, and less than $I$ thereafter. This evolution is statistically significant $(\mathrm{P}<0.0 \mathrm{I})$. It is indeed a very constant phenomenon as a decreased ratio is always observed in individual charts ( 12 cases) when data of the first three months are compared to later measurements. 


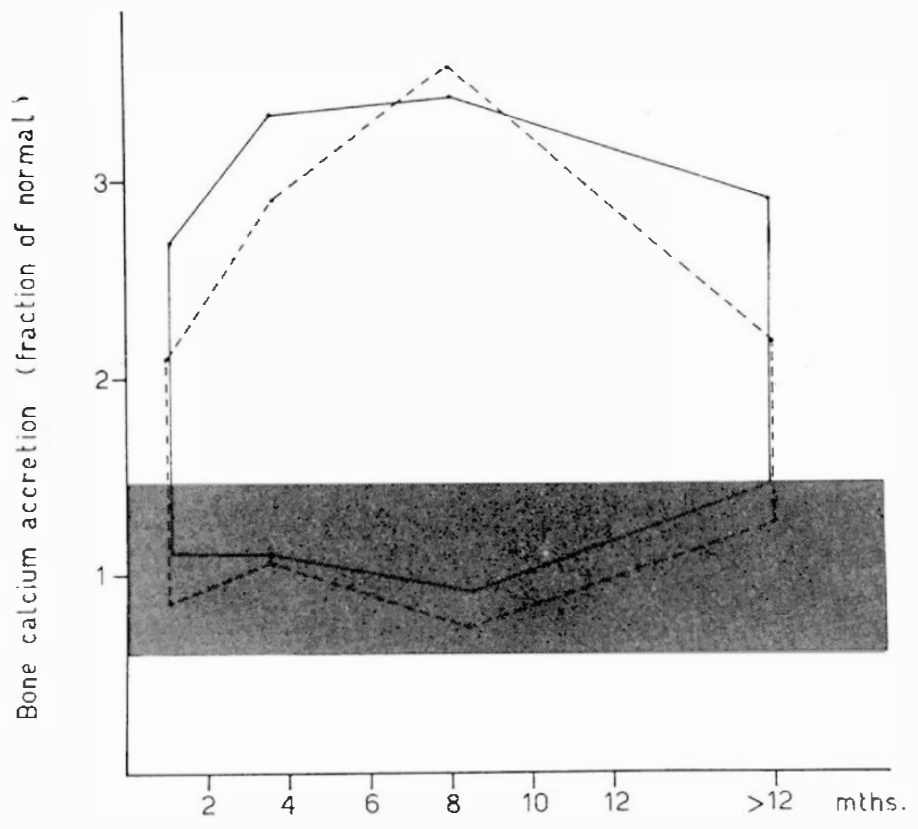

Fig. 3

Bone calcium accretion as a function of time after spinal cord injury. The shaded area: the normal values. The solid lines: one standard deviation for the global accretion. The broken lines: one standard deviation for the accretion limited to regions without fractures or POA.

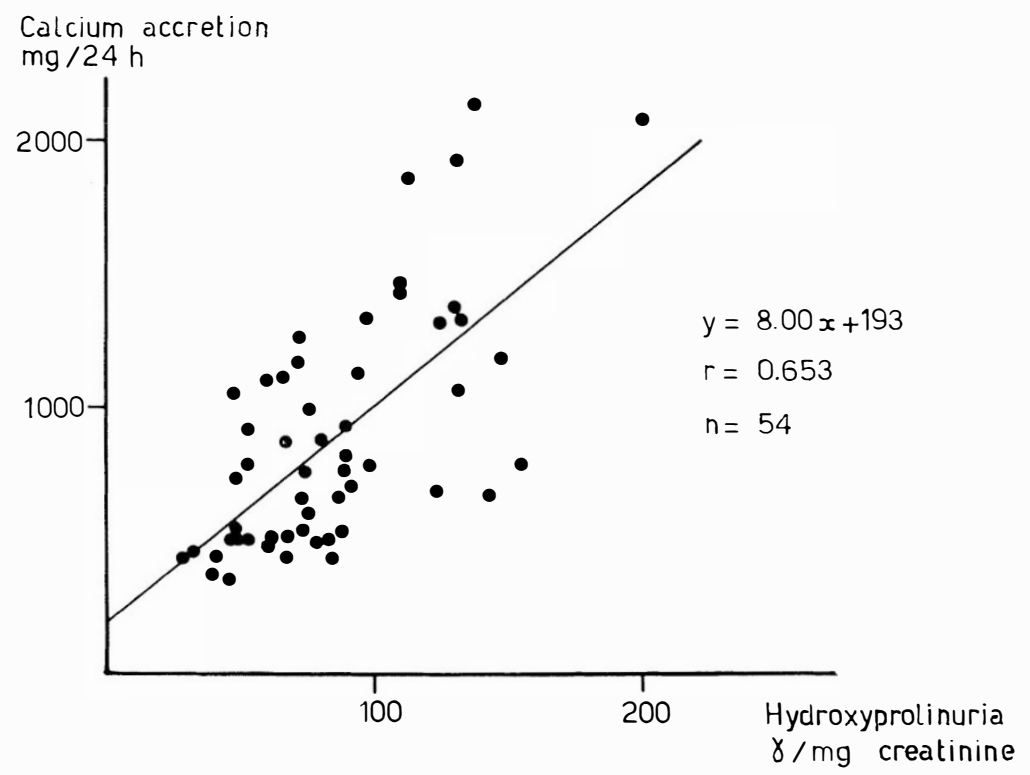

Fig. 4

Calcium accretion and hydroxyprolinuria. 


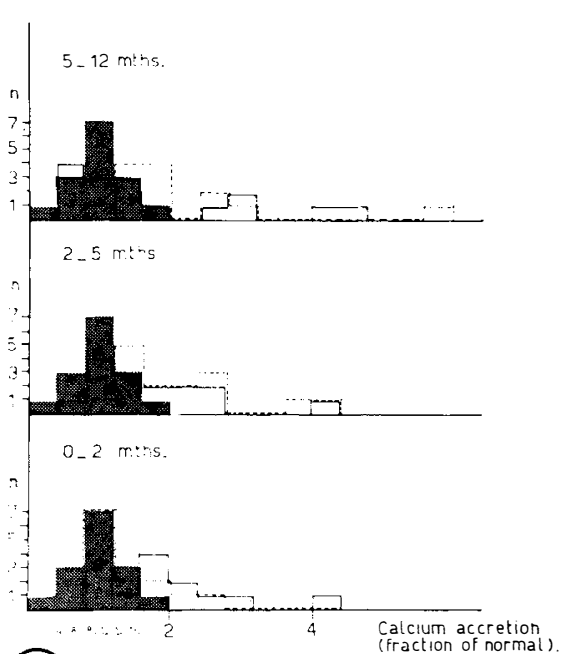

(a)

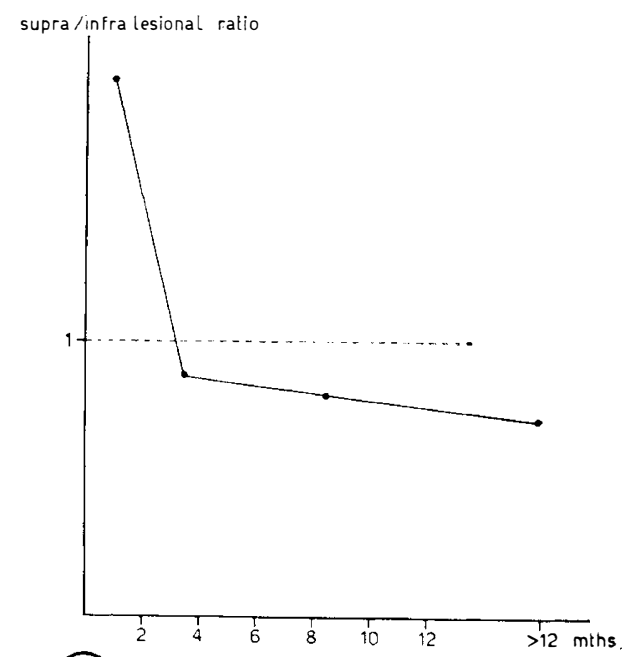

(b)

FIG. 5

(a) Distribution of regional calcium accretion values as a function of time after spinal cord injury. Solid line: supralesional area. The broken line: infralesional area. Shaded: distribution in 15 normal subjects.

(b) Supralesional to infralesional ratio of calcium accretion as a function of time.

Thus, total bone accretion is increased, more so at the supralesional level during the first months after spinal cord injury. At about 3 months, a reversal has occurred, the remodelling becoming more active at the infralesional site.

This natural evolution is independent of known factors, such as spasticity or nursing conditions. Usually, patients assume a sitting position at 3 months. The evolution of the accretion ratio is unaffected in two patients who will sit later.

POA development is accompanied by an early increase of the local accretion value. It reaches a peak and decreases thereafter towards normal values (Fig. 6). It is suggested that surgery for blocked joint should be delayed until after the local calcium turnover returns to a relatively normal pace. In this small series, there seems to be no correlation between the risk of POA development and total accretion values.

\section{Mineralometry}

Nine patients have repeated measurements of their radius mineral content for 7.5 months. In each case, the radius is in the non-paralysed area. The absence of significant modification of its mineral content duririg this period clearly shows that bone balance is in equilibrium in the supralesional area, despite increased remodelling. In one patient, a ro per cent decrease in the bone mineral content of the tibia is measured by the same method, over a period of 3 months.

\section{Leg Circulation}

The arteriovenous shunt of the leg is increased in II patients out of I9. The mean value for paraplegic patients is $15 \cdot 0 \pm 9 \cdot 2$ per cent, thus three times the normal $(\mathrm{P}<0.005) . R_{1} / R_{2}$ is increased in nine patients out of 19 . The mean ratio value is $14.4 \pm 7 \cdot 7$, thus twice the normal $(0.01<\mathrm{P}<0.02)$ (Fig. 7). 

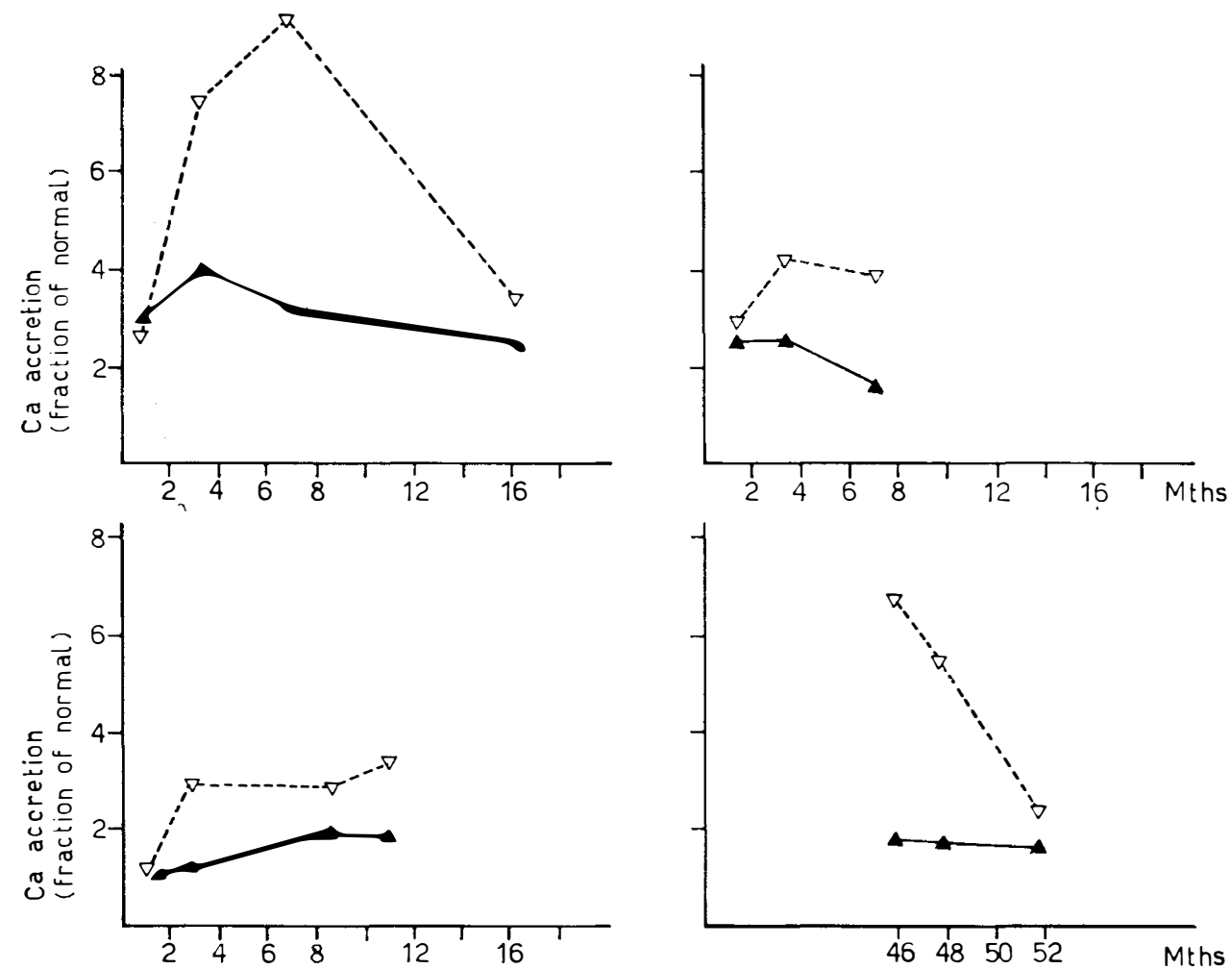

Fig. 6

Regional accretion in the pathological area (broken line) and in the rest of the skeleton (solid line) in four paraplegic patients developing POA.

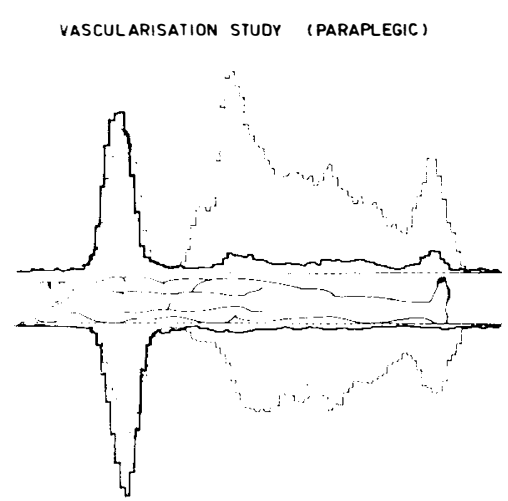

(a)

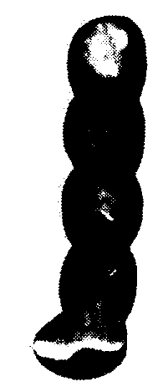

(b)

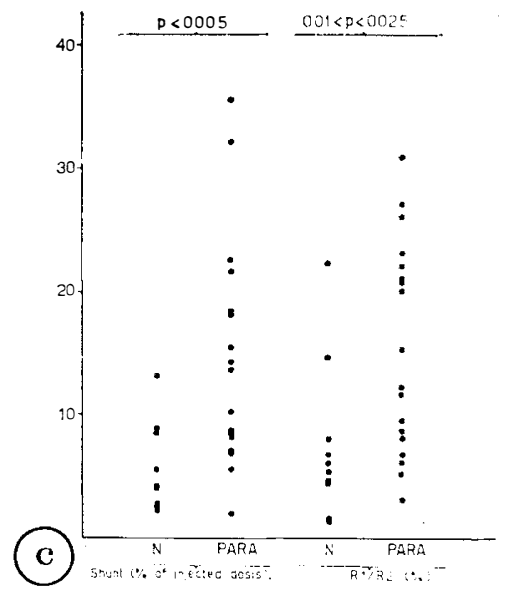

FIG. 7

(a) Activity profile after intrafemoral artery injection of I I3I MAI. An important fraction of the injected dose has embolised into the lungs.

(b) Scanning of the leg of a patient after intrafemoral artery injection of $T_{\mathrm{c}} 99 \mathrm{~m}$ microspheres. Note the high vascularity of the plantar sole.

(c) Arteriovenous shunt and distal vascularisation index in I9 paraplegic patients and ten normal subjects. 


\section{Discussion}

As already known (Chantraine, I97I), spinal cord injury is accompanied by an increased calcium accretion in bone, with a peak between 3 and Io months. Initially bone remodelling is more active in the skeleton of non-paralysed areas but, quickly, this phenomenon increases in the infralesional and decreases in the supralesional region. After 2 months, calcium turnover is greater in the infralesional bone. Calcium balance is not affected in the upper part of the body, as shown by mineralometry, whereas a rapid mineral loss plagues the rest of the skeleton.

Those dynamic data are nowadays only partially confirmed by morphological studies of bone. Remodelling of the infralesional skeleton indeed takes place during the first months, accompanied by an enlargement of bone shafts such as the femoral one (Chantraine et al., 1975). At the same site, poorly calcified bone fractions are more abundant than normal, which is usually presented as indicating the preponderance of newly formed bone (Chantraine, I973). However, tetracycline labelling shows a diminished apposition rate (Minaire et al., 1974). We must admit the difficulty in obtaining a coherent view from both dynamic and histomorphometric data. Nevertheless, one is impressed by the constancy of the evolution of dynamic parameters. Regional accretion can be determined repeatedly, thus permitting the description of the natural history of bone disease in paraplegic patients and making it possible to compare it with other diseases accompanied by acute demineralisation.

Immobilisation from any cause results in a loss of bone mineral, the so-called disuse osteoporosis. Immobilisation indeed leads to remarkable metabolic changes in bone as exemplified by strontium clearance studies (Semb, I968), determinations of $p \mathrm{H}, p \mathrm{CO}_{2}$ and $p \mathrm{O}_{2}$ in bone venous blood (Burkhart \& Jowsey, 1967). Venous stasis could be an important factor in the pathogenesis of disuse demineralisation.

In other respects, some facts are not compatible with the concept of a common mechanism for all disuse osteoporosis.

First, the chronology of events varies from one disease to the other: in poliomyelitis as in immobilised healthy subjects, hydroxyprolinuria is maximal at 2 weeks and calciuria during the $4^{\text {th }}$ week (Dunning \& Plum, I957; Nelson, 1973; Deitrick et al., 1948; Bohr, 1975), whereas these parameters reach a peak at approximately 2.5 months in the patient with spinal cord injury.

We studied seven hemiplegic patients and found a normal calcium accretion with no disparity between paralysed and non-paralysed limbs. In this disease, bone demineralisation is less obvious (Naftchi, 1975) and POA are uncommon, though paraplegia and hemiplegia are similar so far as initial immobilisation and nursing are concerned. The principal discrepancies between the two diseases are age of onset, shortened flaccid period in the hemiplegic patient and sympathetic denervation in paraplegia. The latter could prove important as sympathectomy induces a higher bone blood flow (Brookes, 1973) which could be the stimulus to an enhanced bone resorption (McClugage \& McCuskey, 1973). The hypothesis that a factor different from immobilisation alters bone metabolism is further suggested by the observation in poliomyelitis that initial calciuria is independent of the extent and degree of paralysis as well as of the time of walking and appearance of voluntary muscle function (Dunning \& Plum, 1957). Autonomous nervous system lesion is also part of that disease.

We could demonstrate a significant arteriovenous shunt for particles of circa 
30 microns and an abnormal distribution of the functional capillary bed in the legs of paraplegic patients. Unfortunately, we weren't able to correlate those circulatory abnormalities with either infralesional bone accretion or POA frequency. As long as we have no accurate method at our disposal to measure bone blood flow in man or in intact animals, it will be difficult to study the exact relationship between the autonomous nervous system tonus, bone blood flow and bone metabolism.

The fact that bone turnover, though certainly modulated by local conditions, is stimulated in the whole skeleton of paraplegic patients makes the search for general factors affecting bone metabolism compulsory. Study of circulating hormones only shows a fragility of the hypophyso-adreno cortical axis. Medical stress, however, isn't liable to play an important role in bone pathology since acute medical disease associating stress and strict bed rest during a period of a few weeks is not thought to cause a significant hypercalciuria (Nordin, I973). Opinions diverge on the importance of parathyroid secretion in patients with spinal cord lesions. Some authors present data compatible with PTH suppression (Nordin, 1973) while others find normal (Heath et al., I973) or high (Arnstein et al., I973) PTH values in the serum. Of importance is the demonstration by Burkhart and Jowsey (1967) that parathyroid and thyroid functions are necessary for the development of disuse osteoporosis. So local factors could act by sensitising bone to the action of physiological hormones.

Eventually, calcitonin was found high in the serum of some patients (Chantraine, personal communication).

Besides an hypothetical circulating factor inducing an abnormal bone remodelling, the possibility exists that short and slight variations of serum calcium, ionised calcium and phosphorus could somehow induce a generalised bone metabolic response.

\section{SUMMARY}

A longitudinal study of bone and calcium metabolism in 28 patients with spinal cord lesion has shown: bone remodelling is enhanced, the maximal values being between 3 and Io months; during the first 2 months, bone calcium turnover rate is more elevated in the non-paralysed than in the paralysed area. After 3 months, the reversal is true; the calcium balance remains unchanged in the supralesional area, whereas a rapid loss of bone mineral proceeds infralesionally: a highly significant arteriovenous shunt and an abnormal distribution of blood flow develop in the legs of the subjects.

The study confirms previous observations concerning biological abnormalities in such patients. It brings out the high frequency of elevated phosphorus and alkaline phosphatases in the serum. Abnormalities of the adrenocortical function are frequent.

\section{RÉSUMÉ}

L'étude longitudinale d'un groupe de 28 paraplégiques a permis de montrer les faits suivants: le renouvellement osseux est augmenté et passe par un maximum entre 3 et ro mois; le renouvellement osseux est plus important dans le squelette supralésionnel que dans le squelette infralésionnel au cours des deux premiers mois. La distribution de ce paramètre se modifie ensuite; le bilan calcique reste stable dans la région supralésionnelle, une déminéralisation rapide touchant le squelette infralésionnel; un shunt artérioveineux significatif se développe dans les membres inférieurs. Il existe une distribution anormale du lit capillaire.

L'étude confirme les observations classiques portant sur l'évolution de la biologie, tout en soulignant toutefois la fréquence de l'élévation de la phosphorémie, des phosphatases alcalines et des altérations du métabolisme corticosurrénalien. 


\section{ZUSAMMENFASSUNG}

Das Studium einer Gruppe von 28 Querschnittgelähmten hat folgendes gezeigt: die Knochenerneuerung nimmt zu und erreicht ein Maximum nach 3 bis Io Monaten; im Laufe der 2 ersten Monaten ist die Knochenerneuerung wichtiger über als unter der Verletzungshöhe; die Verteilung dieses Parameters ändert sich aber nachher. Der Kalzium umlauf bleibt stabil in den Knochen über der Verletzungshöhe weil sich die Knochen unter der Verletzungshöhe schnell demineralisieren; ein bedentsamer Shunt entwicklet sich in den Blutgefässen der unteren Extremitäten. Es besteht auch eine abnormale Blutverteilung in den haarfeinen Gefässen.

Dieses Studium bestätigt die klassiche Beobachtungen die sich auf die Entwicklung der Biologie beziehen. Es unterstreicht jedoch die Häufigkeit der Phosphoremie, der laugensatzartigen Phosphatasen under den Stoffwechselstörungen im Rinde der Nebennieren.

\section{REFERENCES}

Arnstein, A. R., McCann, D. S., Blumenthal, F. S. \& Prunty, J. (1973). Clinical Aspects of Metabolic Bone Disease, p. 253. Amsterdam: Excerpta Medica, Boy Frame et al. (Ed.).

Baud, C. A., Pouezat, J. A. \& Very, J. M. (1972). Symposium sur les paraosteoartropathies. C.E.C.A., Luxembourg, pp. $27 \mathrm{I}-275$.

Bauer, G. C. H., Carlsson, A. \& Lindquist, B. (1956). Acta Phys. Scand. 35, 56-66.

Bergmann, P., Schoutens, A. \& Corvilain, J. (I975). Rad. Isot. Klin. Forch. II Band, $30 \mathrm{I}-308$.

Bohr, H. (1975). Calcium Metabolism, Bone and Metabolic Bone Disease, pp. 39-42. Kuhlenfordt F., Kruse H. P. (Eds.). Springer Verlag, Berlin.

Brookes, M. (1973). La circulation osseuse normale et pathologique, pp. 3-13. Paris, INSERM, I rer Colloque International sur la Circulation Osseuse, Toulouse.

BURKHART, J. M. \& JowSEY, J. (1967). Endocrinology, 81, I053-IO52.

Chantraine, A. (197I). Paraplegia, 8, 253-259.

Chantraine, A. (I973). F. Belge Rhum. Méd. Phys., 28, 5-13.

Chantraine, A., Chapard, R. \& Leroux, G. (I975). Ier Symposium C.E.M.O. La Chaux de Fonds, 5-8 octobre.

Decoulx, P., Ducloux, M., Willot, J., Cecile, J. P., Robin, H., Lob, G. \& Leleu, J. C. (1952). Lille Chir. 27, 5 I-83.

Deitrick, J. E., Whedon, G. D. \& Shorr, E. (I948). Amer. F. Med., 4, 3-36.

Dunning, M. F. \& Plum, F. (1957). Arch. Int. Med. 99, 716-731.

Galibert, P., Fossati, P., Lopez, C., Cecille, J. P., Bonte, G., Decoulx, P. \& Laine, E. (196I). Neurochirurgie, 7, I8I-20I.

Heath, H. III, Schaaf, M., Wray, H. L., Monchik, J. M. \& Earll, J. M. (I973). Clinical Aspects of Metabolic Bone Disease, pp. 257-260. Amsterdam: Excerpta Medica, Boy Frame et al. (Ed.).

McClugage, S. G. \& McCuskey, R. S. (I973). Microvascular Research, 6, I32-134.

Marshall, J. H. (1969). Mineral Metabolism, pp. I-I22. Comar C. L. and Bronner, F. (Eds.). Academic Press, New York.

Minaire, P., Meunier, P., Edouard, C., Bernard, J., Courpron, P. \& Bourret, J. (I974). Calcif. Tis. Res. 17, 57-73.

Muheim, G., Donath, A. \& Rossier, A. B. (1973). Amer. F. Roentg. Radium Ther. I18, 865-869.

Naftchi, E. (1975). Arch. Phys. Med. Rehabil. 56, 487-492.

Nelson (1973). Clinical Aspects of Metabolic Bone Disease, p. 260. Amsterdam: Excerpta Medica, Boy Frame et al. (Eds.).

Nordin, B. E. C. (1973). Metabolic Bone and Stone Disease, pp. 43, 45. Churchill Livingstone, Edinburgh and London.

Nusgens, B. \& Lapiere, C. M. (I975). Ier Symposium C.E.M.O., La Chaux de Fonds, 5-8 octobre.

Rhodes, B. A., Greyson, N. D., Hamilton, C. R., White, R. I., Giargiana, F. A. \& WAGNER, H. N. (1972). Nerw Engl. F. Med. 287, 686-689.

SEMB, H. (1968). Surg. Gyn. and Obst. 127, 275-281.

TRICOT, A. (1972). Symposium sur les paraosteoarthropathies. C.E.C.A., Luxembourg, pp. 49-57. 


\section{Discussion to Dr Bergmann's Paper}

DR HARDY (G.B.). Many of our cases of heterotopic ossification occur within 3 months of the injury and the earliest case that I have seen started in I 9 days. How does this clinical observation fit in with your data which seems to me to suggest that changes were not going to happen until after 3 months.

Dr BERGMANN. We didn't see in the small group that we studied, the relation between the metabolic disturbances, metabolic bone turnover rate, and the appearance of paraosteoarthropathy.

DR MINAIRE (France). Have you observed hypercalcaemia in your patients?

DR BERGMANN. No, generally usually calcium remains in normal limits, a few points in all our determinations that were slightly outside the limit the mean +2 standard deviation, but we are not finding hypercalcaemia.

DR MINAIRE. What was the age of your youngest patient?

DR BERGMANN. Seventeen.

DR MINAIRE. What was the duration of your longitudinal study? The minimum and the maximum of the study for calcium exploration.

DR BERGMANN. The follow-up was 6 to 8 months and the beginning of the study was less than 3 months after the spinal injury for 23 patients, whereas in the other five patients we had later datas.

DR BERNARD (France). I think that 6 months is just the minimal duration of such a study because we performed such a study about 3 years ago in Lyon and we realised using quantitative histology examinations that the new steady state of the paralysed bone was obtained at 6 months, about 25 weeks. Therefore, to be sure about the bone turnover and all this question you may have a duration of 12 months at least.

DR RosSIER (U.S.A.). I think that your findings fit very well some of ours and corroborate in fact some of our findings, and I was very much interested in your statement that the shunt is not because of heterotopic bone ossification, I fully agree with you. The reverse is also true: I mean that when in a patient who doesn't have shunt initially when he develops heterotopic bone ossification then he also develops shunt, therefore they are the consequence and not the cause. I fully agree with you.

Dr Dinsdale (Canada). I am interested in where you hypothesize the shunts in the lower extremities in paraplegics. Where do you think they are occurring and what is the mechanism?

DR BERgMANN. Some authors have already described shunts by arteriographic methods and as to the mechanism it is supposed that the sympathetic lesion associated with spinal cord injury would be the cause of vascular disturbances in the paralysed lesions. 